\title{
ORGANIZED LABOR VIEWS THE LOAN SHARK PROBLEM
}

\author{
J. Albert Woll*
}

Perhaps nothing illustrates so pointedly why organized labor continues its active interest in installment loan and finance legislation than a look at those whose welfare this legislation seeks to protect.

One of the largest consumer finance companies in the world says that skilled and semi-skilled craftsmen comprise about $5^{8}$ per cent of their customers. Another 18 per cent are in the unskilled category. Thus, more than 75 per cent are "Labor's own."

Their problems are those which labor seeks to mitigate through education, good wages, stable employment, and wise social legislation. Nevertheless, repeated upsets and emergencies will occur in the life of the average American family and cause even the well paid, thrifty, and best-intentioned to run into financial difficulty.

The butcher, baker, and grocer cannot continue in business on unpaid bills. Nor can the doctor and dentist defer payment indefinitely no matter how lenient they may be willing to be for a time.

How to satisfy each pressing creditor and keep the family a going concern are problems to which a stretched-out paycheck does not provide the answers. A legitimate financing or refinancing service to which families may turn is essential if bankruptcy or charity are to be avoided. American wage earners will not resort to charity or bankruptcy except as a last, desperate resort. They will honor their obligations if at all possible. Experience during the depression proved that losses on debts owed individually by the American people were only a fraction of those incurred on business loans. In the light of this fact, it is ironic that for so long a time, financing of business for production was considered to be constructive while financing the consumer was "bad."

Today, depending on his credit-worthiness and locality, the American consumer has a choice between a commercial bank, an industrial bank, an industrial loan company, a credit union or a small loan company. If he has something specific to pledge he may go to a pawnbroker. In addition, there are numerous sales finance companies who will be delighted to finance his purchase of an automobile, refrigerator, washing machine or television set so that he may enjoy the fruits of the American system to which his own productivity contributes so much.

Fortunately, his financing choice of last resort-the greedy, unregulated loan shark-is fighting a losing battle as new states enact remedial consumer loan laws

- General Counsel, American Federation of Labor. 
and banks and credit unions expand their activities further into the personal installment loan field.

A couple of generations ago, American wage earners in need of short-term financial assistance were almost exclusively at the mercy of loan sharks who would charge all that traffic would bear. Interest rates up to 1,000 per cent per annum were not uncommon, and 20 per cent per month was routine.

The industrial revolution brought not only much material wealth to the American people, but also many evils like sweatshops and child labor. It maimed and cast out on society hundreds of derelicts; it made men old before their time. It also created conditions ideal for the development of loan sharkery on a vast scale because the average American family became increasingly dependent upon the bread-winner's pay check for even the simplest wants. Most of the self-reliance of an agricultural society and its ability to provide at least elemental food, shelter, and clothing disappeared into the maw of an industrial ogre. Reforming both the ogre and the loan shark were twin endeavors of organized labor and labor not only has encouraged this reformation but has done so within the framework of the enterprise system and without destroying profits.

It is obvious that pay checks must come regularly if families are to live normal lives. Any prolonged sickness or unemployment or similar family tragedy sets up a chain of events which generally drag out to an anchor of debt. However, so long as responsible sources of consumer credit are available at reasonable cost commensurate with the risk and expense of doing business, the family will rehabilitate itself with the perseverance and self-sacrifice typical of Americans.

No amount of perseverance and self-sacrifice, however, could cope with the rapaciousness of the loan shark, and organized labor was quick to see the advantage of encouraging the formation of cooperative credit unions and supporting regulatory small loan legislation which would be sufficiently attractive to permit legitimate capital to help fill the gap. This joint encouragement is clearly indicated in the following excerpt taken from the Report of the Executive Council of the American Federation of Labor to the 5ist Annual Convention held October 5, I93I in Vancouver, British Columbia: ${ }^{1}$

Credit Unions and Small Loans-Bills to permit the establishment of credit unions and to protect small loan borrowers, were introduced in the Senate and House. The credit union bill provided that any seven or more persons in the District of Columbia could incorporate and do business. This would permit groups of people working together in any government department to organize a credit union for the purpose of loaning money to its members.

As this would not protect three-quarters of the people in the District, who would not be in a position to form credit unions, the small loan bills were introduced in their interest. Officers of the Washington Central Labor Union complained that "loan sharks" were charging from I00 per cent to 500 per cent for small loans. The small loan bills were

\footnotetext{
${ }^{2}$ Report of the Proceedings of the 5ist Annual Convention, American federation of Labor $1 I_{4}$ (I93I).
} 
reported favorably to both houses and were lost in the congestion. The American Federation of Labor supported both the credit unions and the small loan bills in an effort to drive the "loan sharks" out of business.

It is significant that in the intervening years no substantial progress has been

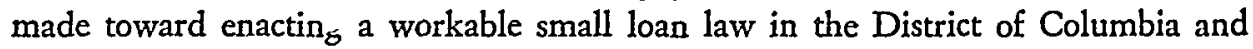
it still has a festering loan shark problem.

Perhaps the best summation of labor's attitude toward the loan shark problem appeared in the April, I933 issue of the American Federationist, official publication of the A. F. of L.: $^{2}$

The problem of credit for those who need small loans and are not served by the banks and other credit agencies which consider this type of loan too hazardous and too expensive in collection, has long been either neglected or overlooked entirely. Yet credit to persons of small incomes may be essential to tide over emergencies and to prevent the loss of a lifetime's savings. Where credit provisions are not made for the numerically large proportion of our population their recourse is the loan shark, always waiting for a victim.

The practical thing to do seems the enactment of small loan bills by states, fixing interest at the lowest rate per month that the industry can accommodate. Experience under such a measure probably would indicate practices that would make possible reduction in rates. The way to make progress with this problem is to take a step that promises results and then determine the next move.

The late A. F. of L. President, William Green, personally went on record many times in many places for remedial lending legislation. Under the by-line of Harry N. Mullican in the Louisville (Ky.) Herald-Post of December 26, 1933, there is quoted a long letter of Mr. Green's complimenting the Post for its efforts and saying in part:

Labor has always strongly regarded the loan shark practice as a real evil. Because of this fact Labor has led in the fight which has been made in the different states to secure remedial legislation. We have endeavored with all the power we possess to eliminate through legislative action the evil practices followed by loan sharks and loan shark organizations.

While we recognize it is an evil, we have found that it is only through the enactment of small loan legislation similar in character to that proposed and supported by the Russell Sage Foundation that we can even in a small degree help the victims of the small loan sharks and make provisions for harassed laboring people to secure loans at a more reasonable cost.

Martin P. Durkin, until recently United States Secretary of Labor, interested himself in this problem when he was President of the International Association of Governmental Labor Officials to the extent of appointing a "Special Committee on Small Loans" under the Chairmanship of E. P. Patton of the New York Department of Labor. Mr. Patton in his report to the next convention at Tulsa, Oklahoma (September, I939), expressing his amazement "when I discovered the extent of this

${ }^{2}$ Editorial, Small Loan Bill, 40 American Federationist 345-346 (1933). 
sort of thing," stated, "I thoroughly believe that we should all exert our efforts to securing the wisest, sanest small loan statutes in each of our states. I am inclined to believe that its supervision should be in some other department, preferably the State Banking Department."

Labor has not limited its interest in the promotion and defense of appropriate legislation to the administrative and legislative halls. Through its general counsel, the late Joseph A. Padway, the A. F. of L. joined issue with the loan sharks in the courts and intervened successfully, amicus curiae, in State ex rel. Moore v. Gillian, ${ }^{3}$ and State ex rel. Goff $\nu$. O'Neil. ${ }^{4}$

Justifying his intervention in the courts, Attorney Padway stated:

Part of the functions of the American Federation of Labor is to give all aid possible to state federations of labor in their legislative and legal problems which are of statewide concern and which may have the effect of establishing precedents of great value nationally. The Minnesota Federation of Labor has requested the assistance of the American Federation of Labor in this case and it is of such importance that the American Federation of Labor is anxious to comply. Accordingly, the American Federation of Labor has requested this court to permit this intervention in the capacity of a friend of the court, and in doing so, is acting in furtherance of the interests of the workers of the State of Minnesota and of the workers of the nation.

Perhaps it is difficult for some to evaluate labor's "intervention" in the consumer credit field. Organized labor itself has no such difficulty. Labor has championed increased wages, shorter hours, improved housing, pensions, stabilized employment, unemployment insurance, and many "benefits" which it looks upon not alone "in furtherance of the interests ... of the workers of the nation" but of the nation itself. In the same light it champions constructive consumer credit and the elimination of loan sharkery. Most recently, various segments of labor have voiced opposition to "Regulation W" which authorized the Federal Reserve Board to control consumer credit. This authority, exercised on and off since I94I, has since been killed by Congress.

A primary aim of labor is stable employment and nothing is so interdependent as regular employment and consumer credit. Without reasonably stable employment, consumer lending and financing would be haphazard, excessively costly, and probably of insufficient volume to move the vast quantity of consumer durable goods which must flow in orderly fashion from factory to family if America is to remain prosperous.

In the field of emergency cash lending, the need is to rehabilitate families-to make them solvent, going concerns so that they may be pulled back into the economic stream of the nation. There must be legitimate sources from which to obtain this emergency cash credit because the loan shark can never function as a rehabilitator. His charges are so exorbitant that they sap the financial vitality of his victim who finds it almost impossible to do more than keep his own body and

${ }^{3}$ I I Fla. 707, I93 So. 75I (1940).

t 205 Minn. 366, 286 N. W. 316 (1939). 
soul together while maintaining the shark in the style to which he is accustomed.

Banks and credit unions have expanded greatly in the field of consumer credit in the period since I94I when Law and Contemporary Problems devoted its entire Winter edition to the theme, "Combating the Loan Shark." They are rendering a great service, both in direct personal loans and in the broader field of financing of consumer durable goods. Nevertheless, the shocking experience in those states which have not enacted a regulatory law of the type sponsored by the Russell Sage Foundation, is an indication that banks and credit unions do not compete sufficiently with the loan shark to give substantially enough relief to his victims. This is not said in criticism of either the banks or the credit unions. It must be recognized that the lending area where loan sharks thrive is not usually one where depositors' money may be safely risked nor costs recouped at conventional interest rates.

Unfortunately, in the dozen intervening years, the number of unregulated states which have substantially improved their loan legislation is not as great as those which have not. Dr. William Trufant Foster's analysis of small loan laws of the United States $^{5}$ (based on I940 data) showed I3 $_{3}$ states without any small loan laws and 5 with largely or wholly inoperative laws-to which should be added the District of Columbia, as we have already indicated. The following table gives the present status of these 19 jurisdictions:

Arkansas-Effective regulation enacted in 195I; negated by Supreme Court in 1952.

Delaware-Improved but ineffective regulation enacted in 1945 .

District of Columbia-No change.

Georgia-No change.

Idaho-Effective regulation enacted in 1943.

Kansas-No change.

Mississippi-No change.

Montana-No change.

Nevada-Effective regulation enacted in 1943 and additional constructive legislation in $195 \mathrm{I}$.

North Carolina-Ineffective regulation enacted in 1945 .

North Dakota-No change.

Oklahoma-Effective regulation enacted in $\mathrm{r} 94 \mathrm{I}$.

South Carolina-No change.

South Dakota-Effective regulation enacted in 1953.

Tennessee-No change.

Texas-Ineffective statutes enacted in 1943, 1949, I951.

Washington-Effective regulation enacted in 1941 .

Wyoming-Effective regulation enacted in 1953 .

Since loan sharks have folded up wherever remedial loan laws have been enacted within the foregoing jurisdictions, and conversely, have continued to flourish in the remainder, the conclusion is inescapable that competition from lawful lenders specializing in this area to a greater extent than credit unions, banks, and others do, seems to be a far more effective control device than strictly punitive or completely

${ }^{-}$The Personal Finance Business Under Regulation, 8 LAW \& ConteMp. Prog. I54 (1941). 


\begin{tabular}{|c|c|c|c|c|c|c|c|c|c|}
\hline \multirow[b]{2}{*}{$\begin{array}{l}\text { LoAN } \\
\text { CoMPANY }\end{array}$} & \multicolumn{3}{|c|}{$\begin{array}{l}\text { Loans from } \$ 25.00 \text { to } \\
\$ 74.99 \text { Inclusive }\end{array}$} & \multicolumn{3}{|c|}{$\begin{array}{l}\text { Loans from } \$ 75.00 \text { to } \\
\$ 299.99 \text { Inclusive }\end{array}$} & \multicolumn{3}{|c|}{$\begin{array}{l}\text { Loans from } \$ 300.00 \text { to } \\
\$ 999.99 \text { Inclusive }\end{array}$} \\
\hline & Number & $\begin{array}{l}\text { Average } \\
\text { Rate of } \\
\text { Interest }\end{array}$ & $\begin{array}{l}\text { Highest } \\
\text { Rate of } \\
\text { Interest }\end{array}$ & Number & $\begin{array}{l}\text { Average } \\
\text { Rate of } \\
\text { Interest }\end{array}$ & $\begin{array}{l}\text { Highest } \\
\text { Rate of } \\
\text { Interest }\end{array}$ & Number & $\begin{array}{l}\text { Average } \\
\text { Rate of } \\
\text { Interest }\end{array}$ & $\begin{array}{l}\text { Highest } \\
\text { Rate of } \\
\text { Interest }\end{array}$ \\
\hline 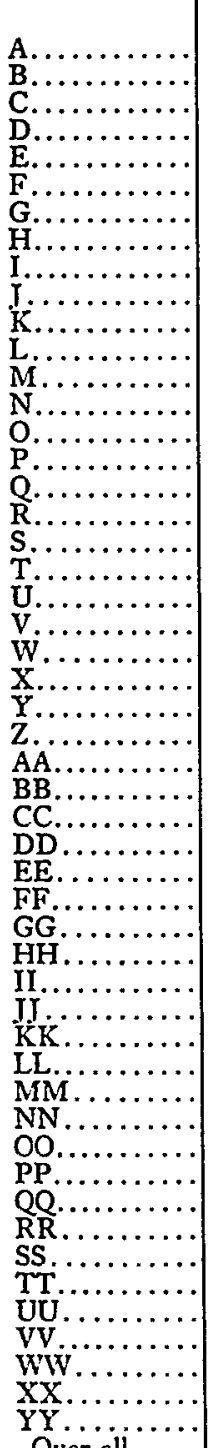 & $\begin{array}{r}23 \\
76 \\
43 \\
37 \\
57 \\
32 \\
5 \\
36 \\
55 \\
111 \\
9 \\
67 \\
68 \\
59 \\
21 \\
23 \\
38 \\
25 \\
60 \\
5 \\
1 \\
4 \\
53 \\
30 \\
38 \\
74 \\
106 \\
5 \\
3 \\
8 \\
34 \\
4 \\
10 \\
4 \\
17 \\
81 \\
36 \\
29 \\
17 \\
85 \\
8 \\
7 \\
26 \\
3 \\
11 \\
1 \\
54 \\
26 \\
5\end{array}$ & $\begin{array}{r}\text { Per Cent } \\
\because 35.1 \\
262.7 \\
216.3 \\
193.2 \\
207.2 \\
220.3 \\
179.6 \\
268.3 \\
275.8 \\
230.0 \\
45.6 \\
114 . .5 \\
139.8 \\
103.6 \\
107.7 \\
112.1 \\
96.6 \\
72.0 \\
22.2 \\
65.6 \\
45.0 \\
125.0 \\
141.6 \\
136.9 \\
100.2 \\
228.0 \\
223.1 \\
76.8 \\
25.6 \\
64.0 \\
113.8 \\
65.0 \\
60.9 \\
64.7 \\
44.9 \\
119.7 \\
90.3 \\
126.1 \\
102.7 \\
138.7 \\
160.7 \\
92.5 \\
103.2 \\
72.0 \\
101.1 \\
240.0 \\
141.7 \\
47.3 \\
123.3 \\
\end{array}$ & \begin{tabular}{|r|} 
Per Cent \\
$\ldots 96$ \\
294 \\
275 \\
268 \\
275 \\
285 \\
266 \\
275 \\
294 \\
275 \\
80 \\
235 \\
252 \\
234 \\
143 \\
142 \\
158 \\
264 \\
160 \\
30 \\
93 \\
45 \\
240 \\
271 \\
288 \\
264 \\
275 \\
272 \\
132 \\
32 \\
144 \\
250 \\
153 \\
219 \\
107 \\
96 \\
275 \\
264 \\
240 \\
180 \\
252 \\
236 \\
252 \\
216 \\
78 \\
168 \\
240 \\
252 \\
120 \\
280 \\
\end{tabular} & $\begin{array}{r}24 \\
7 \\
2 \\
66 \\
40 \\
25 \\
24 \\
28 \\
23 \\
25 \\
6 \\
9 \\
8 \\
24 \\
40 \\
15 \\
45 \\
\\
23 \\
9 \\
6 \\
22 \\
34 \\
18 \\
20 \\
20 \\
23 \\
49 \\
64 \\
24 \\
23 \\
44 \\
24 \\
16 \\
27 \\
40 \\
14 \\
14 \\
10 \\
53 \\
10\end{array}$ & $\begin{array}{c}201.0 \\
24.5 \\
40.5 \\
57.2 \\
67.1 \\
59.8 \\
62.7 \\
56.7 \\
35.9 \\
28.2 \\
5.5 \\
37.4 \\
24.3 \\
48.2 \\
66.2 \\
55.8 \\
37.8 \\
\\
136.1 \\
30.1 \\
19.0 \\
31.6 \\
49.1 \\
35.4 \\
52.1 \\
69.0 \\
23.9 \\
38.6 \\
48.8 \\
43.5 \\
37.5 \\
56.4 \\
37.6 \\
44.5 \\
58.0 \\
65.7 \\
34.8 \\
29.2 \\
151.3 \\
24.8 \\
46.9\end{array}$ & $\begin{array}{r}293 \\
36 \\
70 \\
87 \\
161 \\
117 \\
96 \\
100 \\
80 \\
80 \\
12 \\
52 \\
52 \\
140 \\
200 \\
119 \\
96 \\
\\
208 \\
76 \\
24 \\
80 \\
111 \\
102 \\
135 \\
161 \\
46 \\
76 \\
141 \\
120 \\
66 \\
144 \\
103 \\
72 \\
153 \\
209 \\
48 \\
46 \\
672 \\
76 \\
140\end{array}$ & $\begin{array}{r}3 \\
1 \\
17 \\
9 \\
11 \\
10 \\
13 \\
64 \\
16 \\
33 \\
10 \\
12 \\
16 \\
19 \\
9 \\
15 \\
27 \\
6 \\
10\end{array}$ & $\begin{array}{r}5.0 \\
16.0 \\
15.4 \\
42.4 \\
20.9 \\
18.2 \\
31.2 \\
14.7 \\
22.0 \\
26.0 \\
37.9 \\
27.5 \\
36.2 \\
19.6 \\
24.2 \\
20.1 \\
78.4 \\
29.1 \\
12.5\end{array}$ & $\begin{array}{r}8 \\
16 \\
24 \\
120 \\
45 \\
34 \\
58 \\
38 \\
38 \\
69 \\
72 \\
35 \\
67 \\
33 \\
41 \\
36 \\
203 \\
37 \\
29\end{array}$ \\
\hline $\begin{array}{l}\text { Average Rate } \\
\text { of Interest... }\end{array}$ & $\cdots$ & 127.3 & $\cdots$ & $\cdots$ & 54.4 & $\cdots$ & $\cdots$ & 28.9 & \\
\hline
\end{tabular}

Highest rates of interest remorted represent highest individual loan rates found among the loans reported by the various

small loan companies for each of the three principal categories. ins of individual loan rates are reported in terms of fractional percentage points. 
prohibitory measures. Prohibition seems to be no more effective against bootleg lending than against bootleg liquor.

Picking out 2 states at random on which some recent statistical information is readily available, we note that although they are miles apart geographically and to some extent politically, economically and philosophically, they have had-until very recently-one thing very much in common-extortionate loan sharks. For these illustrations, we have used the State of South Dakota, the most recent state to enact an adequate small loan law, and the State of South Carolina which is still in the "no small loan law" category.

The official Journal of the Senate of the State of South Dakota for the third legislative day, January 8, r953, contains a report of Attorney-General Ralph A. Dunham, in which he sets forth some of his findings as follows (see page ror):

Unfortunately there is no similar official state document available for the State of South Carolina but we have been able to obtain a printed rate chart put out by a lender operating 2 offices in the state. This chart contains merely 2 columns, "Net Proceeds" and "Provision for Payment." In the following table we have changed these 2 headings to the more enlightening "Cash Advanced to Borrower" and "Monthly Payment" and for further enlightenment, we reveal what the borrower seldom finds out for himself-his total loan obligation, his total charges, and what percentage rate of interest he is actually paying: (in the interest of saving space, we have eliminated from this particular rate chart the columns for 15 and I8 month maturities but the pattern is essentially the same).

Finance Payment Schedule

\begin{tabular}{|c|c|c|c|c|}
\hline $\begin{array}{l}\text { Total Loan } \\
\text { Obligation }\end{array}$ & $\begin{array}{l}\text { Cash Advanced } \\
\text { to Borrower }\end{array}$ & Monthly Payment & Total Charges & $\begin{array}{c}\text { Effective Gross } \\
\text { Annual Rate When } \\
\text { Paid out According } \\
\text { to Maturity }\end{array}$ \\
\hline \multicolumn{5}{|c|}{ Sixth Month Loans } \\
\hline $\begin{array}{r}\$ 30.00 \\
60.00\end{array}$ & $\begin{array}{r}\$ 20.35 \\
47.35\end{array}$ & $\begin{array}{l}\$ 5.00 \\
10.00 \\
\quad \text { etc. } \\
\text { etc. }\end{array}$ & $\begin{array}{r}\$ 9.65 \\
12.65\end{array}$ & $\begin{array}{r}162.6 \\
86.4\end{array}$ \\
\hline \multicolumn{5}{|c|}{ Twelve Month Loans } \\
\hline $\begin{array}{r}\$ 60.00 \\
72.00\end{array}$ & $\begin{array}{l}45.64 \\
55.90\end{array}$ & $\begin{aligned} 5.00 & \\
6.00 & \\
& \text { etc. } \\
& \text { etc. }\end{aligned}$ & $\begin{array}{l}14.36 \\
16.10\end{array}$ & $\begin{array}{l}54.0 \\
49.2\end{array}$ \\
\hline
\end{tabular}

High as these rates may appear, they are substantially less than those revealed in the South Dakota study. Probably, therefore, as can be seen from the foregoing, despite the listing of higher loan categories and longer maturities in the payment schedule, the loan shark may reap exorbitant percentage rates of return by the simple process of making only the smaller loans for short maturities. On the other hand, 
this particular company may be one of those occasional "better loan sharks" attempting to set realistic rates with a loading factor for operating in evasion of the law. In any event both the South Carolina and the South Dakota illustrations prove that the loan shark operates essentially the same today as when organized labor and other public-spirited groups first began to seek his elimination. The progress has not been in mitigating the activity of the individual loan shark-only in reducing his number. 